\title{
Peran Forum Koordinasi Pencegahan Terorisme dalam Menjalankan Program Deradikalisasi
}

\begin{tabular}{|c|c|}
\hline \multicolumn{2}{|c|}{$\begin{array}{c}\text { Mohamad Rapik }^{\mathbf{1}^{*}} \text {, Bunga Permatasari }{ }^{\mathbf{1}} \text {, Adinda Farah Anisya }{ }^{\mathbf{1}} \\
{ }^{1} \text { Fakultas Hukum, Universitas Jambi, } 36122 \text { Muaro Jambi - Jambi, Indonesia }\end{array}$} \\
\hline Info Artikel: & ABSTRAK \\
\hline $\begin{array}{l}\text { Dikirim: Nov 27, } 2019 \\
\text { Diterima: Jan 27, } 2020 \\
\text { Dipublikasi: Jan 28, } 2020\end{array}$ & $\begin{array}{l}\text { ABSTRACT, This article aims to elaborate an empirical study on the role of the } \\
\text { FKPT (Coordintaing Forum on The Eradication of Terrorism). This article is based } \\
\text { on an assummtion that the FKPT is a vital agent hoped to play a significant role of } \\
\text { dradicalisation. The study was conducted to proof as to wether this assumtion is right }\end{array}$ \\
\hline $\begin{array}{l}\text { Kata Kunci: } \\
\text { Deradikalisasi; } \\
\text { FKPT; } \\
\text { Terorisme; }\end{array}$ & $\begin{array}{l}\text { or wrong by observing the performaance of this agent. In addition to study of its } \\
\text { performance, the article also focuses on the issue of deradicalisation on the assumtion } \\
\text { that it is program that the FKPT should play its role. Any affort to eradicate terrorism } \\
\text { should only be efficient through a work of deradicalisation. The essence of this } \\
\text { program is to shift paradigm or mindset which is believed to have been dangerous }\end{array}$ \\
\hline $\begin{array}{l}\text { Koresponden: } \\
\text { Mohamad Rapik, } \\
\text { Fakultas Hukum } \\
\text { Universitas Jambi }\end{array}$ & $\begin{array}{l}\text { and misleading. Applying an empitical legal approach, this study aims to explore } \\
\text { deeply the application of the deradicalisation and its influence in enhanching } \\
\text { community awareness against the danger of terrorism. It is found through this study } \\
\text { that the FKPT, as long as its role is concerned, has been working so efficently by } \\
\text { advocating brokers to dessimanate its mission of deradicalisation. However, the study } \\
\text { also revealed waknessess during its program showing that the community awareness }\end{array}$ \\
\hline $\begin{array}{l}\text { Email: } \\
\text { m.rapik@unja.ac.id }\end{array}$ & $\begin{array}{l}\text { over the danger of the terrorism ideology has not increasingly shifted as the program } \\
\text { might have expected. Istead, as the study revealed, religious extremism seems to have }\end{array}$ \\
\hline Cantuman Sitasi: & $\begin{array}{l}\text { been increased lately. It is suggested through this study that the FKPT work more } \\
\text { expansively reaching the root, especially to the lay people and students as they have }\end{array}$ \\
\hline Rapik, Mohammad, et.al. & mostly been the main target of radicalisation and of potentially terrorism. \\
\hline
\end{tabular}

(2020). Peran Forum Koordinasi Pencegahan Terorisme dalam Menjalankan Program Deradikalisasi. Journal of Political Issues 1(2), 103-114. Doi: https://doi.org/10.33019/jpi.v1 $\underline{\mathrm{i} 2.11}$

\begin{abstract}
ABSTRAK, Artikel ini bertujuan untuk memaparkan secara empirik peran deradikalisasi oleh FKPT. Diawali dari asumsi bahwa FKPT merupakan agen penting dalam melakukan deradikalisasi, maka studi ini berupaya menyorot kinerja dan hasil yang telah dicapai oleh lembaga ini. Di samping sudah menjadi bagian dari kerja FKPT, deradikalisasi menjadi topik makalah ini berdasarkan asumsi bahwa terorisme berawal dari radikalisme. Oleh karena itu, upaya memerangi terorisme lebih efektif melalui deradikalisasi. Esensinya adalah mengubah pemahaman atau pola pikir yang dianggap salah. Dengan menerapkan penelitian hukum empirik, studi ini hendak menjelajahi beberapa hal, yaitu pertama; bagaimana pelaksanaan program deradikalisasi FKPT? Kedua, bagaimana pengaruh program deradikalisasi FKPT bagi masyarakat dalam meningkatkan kesadaran mereka akan bahaya terorisme. Studi ini menemukan bahwa FKPT dalam menjalankan tugaskan bekerja secara efisien dengan memanfaatkan para broker sebagai perpanjangan tangan dalam menyemai misi deradikalisasi. Kelemahan ditemukan manakala teridentifikasi bahwa pemahaman masyarakat masih belum bergeser pada nilai-nilai ideologis yang dikehendaki. Terdapat kecendrungan faham kekerasan agama justru mengalami peningkatan. Karena itu, disarankan agar FKPT bekerja secara lebih luas menjangkau akar rumput, terutama masyarakat dan mahasiswa/pelajar mengingat faham radikalisme yang berpotensi pada tindakan terorisme banyak ditemukan pada kelompok tersebut.
\end{abstract}

Tentang Penulis:

Mohamad Rapik, menyelesaikan studi Magister (S2) pada dua Institusi yaitu IAIN Sultan Thaha Saifudin Jambi pada tahun 2003 dan Universitas Jambi pada tahun 2012. Saat ini penulis adalah dosen Fakultas Hukum di Universitas Jambi.

Bunga Permatasari, menyelesaikan studi Magister (S2) Universitas Jambi pada tahun 2014. Saat ini penulis adalah dosen Fakultas Hukum di Universitas Jambi.

Adinda Farah Anisya, saat ini penulis adalah Mahasiswa (S1) Fakultas Hukum di Universitas Jambi dan aktif pada organisasi Law Science Organization. 


\section{PENDAHULUAN}

Program deradikalisasi belakangan ini menjadi upaya yang serius seiring dengan tetap maraknya aksi-aksi terorisme. Langkah deradikalisasi ini dilakukan dalam rangka pencegahan dini bibit-bibit terorisme akibat pemahaman ideologi yang radikal. Secara potensial, faham radidkal ini dianggap bersifat destruktif dan mampu merasuki hampir semua lapisan masyarakat. Untuk ini, Pemerintah Indonesia bahkan telah mengeluarkan SKB (Surat Keputusan Bersama) untuk mencegah segala macam bentuk radikalisme yang diduga kuat telah menyusup di kalangan untuk ASN (Aparatur Sipil Negara). SKB tersebut bahkan mengamanatkan dibentuknya Satuan Tugas untuk menangani tindakan radikalisme yang terjadi di kalangan ASN yang meliputi sikap intoleran, anti ideologi Panasila, anti NKRI, dan menyebabkan disintegrasi bangsa (SKB 11 Menteri: 2019).

Terorisme sebagai sebuah kejahatan telah ditempatkan sebagai dalam rangking extraordinary crime atau kejahatan yang luar biasa. Namun berbeda dari kejahatan luar biasa lainnya, seperti korupsi dan narkotika, kejahatan terorimse melibatkan pemahaman yang keras namun dianggap legitimate oleh penganutnya. Mengingat sifatnya yang extraordinary dan ideologis, maka pentingnya deradikalisasi dalam konteks penanggulangan tindak pidana terorisme merupakan hal yang tidak dapat dihindari. Pendekatan deradikalisasi berangkat dari suatu asumsi bahwa terorisme berpangkal dari radikalisme. Oleh karenanya, upaya penanggulangan tindak pidana terorisme dinilai akan jauh lebih efektif melalui pendekatan deradikalisasi, yaitu upaya untuk mengubah pandangan dunia atau cara berfikir yang dianggap berbahaya, yaitu dengan menghilangkan unsur-unsur pemikiran dan cita-cita yang bisa membawa manusia pada tindakan terorisme. Upaya ini dilakukan dengan cara memberikan pemahaman baru tentang realitas yang mereka fahami selama secara keliru selama ini, serta menekankan pentingnya sikap-sikap inklusif, toleran, dan moderat tentang isu-isu jihad (Bouzar, 2018)

Dalam konteks Indonesia, menurut Irfan Idris, salah satu akar terorisme adalah faham radikalisme yang diwujudkan dalam bentuk tindakan radikal yang memaksakan kehendak. Menurut Sarlito Wirawan, bahwa para pelaku terorisme adalah orang-orang biasa yang kebetulan memiliki ideologi yang berbeda, yang sangat meyakini seolah-olah ideologi mereka yang paling benar, di luar itu salah dan merusak umat manusia oleh karena harus diperangi (Sarwono, 2012). Ideologi radikal tersebut menurut Fathurin Zen, berakar dari paham dan fanatisme agama atau kepercayaan yang keliru (Zen, 2012).

Perang melawan terorisme telah terbukti mampu melenyapkan atau menangkap sejumlah orang yang diduga sebagai teroris. Namun pada kenyataanya, cara-cara tersebut tidak serta merta mampu menanggulangi kejahatan terorisme. Bahkan dalam banyak hal, tindakan-tindakan represif justru meningkatkan intensitas dan kuantitas kejahatan terorisme. Kejahatan yang dihadapi secara represif tidak jarang jusru melahirkan semacam siklus kekerasan yang bekerja secara simbiosis mutualisme. Terlebih bahwa persoalan ideologis dari terorisme, yang di antaranya menganggap bahwa kelompok di luar mereka adalah kafir dan layak untuk dibinasakan, menjadi faktor pendukung berkembang pesatnya kejahatan ini. Doktrin keselamatan yang mereka yakini menjadi faktor pendorong kalangan teroris untuk melancarkan serangan-serangan mematikan di tempat manapun yang mereka anggap sebagai musuh. Karena itu, tidak sedikit pihak yang kemudian menyarankan bahwa pendekatan dialogis dan bukannya represif jauh lebih efektif dalam menanggulangi kejahatan terorisme.

Sebagai negara hukum yang menjunjung tinggi prinsip-prinsip hukum sebagai panglima, pendekatan hukum (penal) terhadap suatu tindak pidana dianggap sebagai upaya paling efektif dalam menanggulangi tindak pidana terorisme. Despan Heryansyah \& Muhammad Hidayatullah bahkan memandang bahwa penegakan hukum itu teramat penting untuk dilakukan. Jika tidak, maka hukum itu akan mati (Heryansyah, 2018) dan pasti akan menyebabkan rusaknya bangunan dan sistem sosial. 
Sebagai konsekuensi dari upaya penal tersebut, penanggulangan kejahatan terorisme dilakukan melalui proses pemidanaan sebagaimana tindak pidana lainnya. Tujuan yang diharapkan dari pemidanaan tersebut tiada lain adalah untuk mengembalikan dan menetralisir sifat jahat dalam diri seseorang dapat dilakukan, dan selanjutnya mengembalikan orang tersebut pada pelukan sosialnya (Monalisa, 2019). Sekalipun memiliki nilai-nilai etis di balik upaya penal tersebut, faktor-faktor represif tidak bisa dihindarkan. Dengan demikian, upaya pemidanaan seperti itu ternyata tak cukup bekerja untuk membuat jera para teroris. Sebagai kejahatan yang dikembangan melalui proses indoktrinasi, mereka yang sudah menjelma menjadi teroris umunya akan sulit untuk dikembalikan pada keadaan semula. Bahkan beberapa di antara mereka dikabarkan telah menyebar doktrin ideologis terorisme di kalangan para narapidana lainnya.

Salah satu kasus yang menunjukkan gagalnya program deradikalisasi yang dilakukan melalui pendekatan penal adalah lahirnya residivis teroris yang justru bertekad melanjutkan aksi dan merekrut anggota baru. Satu di antara mereka adalah kasus Afif alias Sunakin, pelaku teror bom Thamrin pada 14 Januari 2016. Afif mulai menghuni Lapas Cipinang pada 2011 karena terbukti mengikuti pelatihan bersenjata di Jalin Jantho, Aceh. Afif kemudian dibebaskan pada tahun 2015. Sayangnya, Afif yang sudah melewati proses pemidanaan ternyata kembali melakukan tindakan terorisme padahal sebelumnya ia sudah dianggap terbebas dari unsur-unsur radikal sehingga mendapatkan pembebasan.

Saat berada di Lapas Cipinang, Afif bersama napi lainnya, Kurnia, menjadi murid Aman Abdurrahman. Aman yang dipindah ke Lapas Nusakambangan adalah residivis kasus terorisme. Ia bahkan disebut-sebut sebagai ideolog paham ISIS di Indonesia. Saat di penjara, Aman bukannya terkucil. Ia bahkan mampu merekrut pengikut baru dan mengkoodinir aksi teror. Penjagaan yang demikian ketat di blok penjara khusus narapidana terorisme ternyata belum tentu mampu membuat pelaku terorisme tobat. Penjara yang sangat ketat itu justru menjadi media rekrutmen dan radikalisasi kelompok teror baru (tirto.id, 2019).

Oleh karena itulah, dibutuhkan sebuah badan seperti Forum Koordinasi Pencegahan Terorisme (FKPT) yang lebih kuat agar para teroris tidak lagi menyebarkan terornya dan meresahkan masyarakat. Untuk mewujudkan kehidupan bangsa yang aman dan damai, upaya penanggulangan tindak pidana terorisme melalui program deradikalisasi oleh pihak FKPT menjadi sangat urgen. Namun, keberadaan FKPT di daerah sekalipun tampaknya belum mampu meredam secara signifikan pertumbuhan radikalisme di kalangan masyarakat. Artikel ini berupaya menelisik sejauh mana FKPT Propinsi Jambi sudah melaksanakan fungsi deradikalisasi dalam rangka melakukan upaya penanggulangan tindak pidana terorisme. Demikian pula, artikel ini ingin memaparkan bagaimana pengaruh deradikalisasi FKPT terhadap sikap anti radikalisme serta meningkatkan kesadaran masyarakat akan bahaya terorisme di Propinsi Jambi.

\section{METODE PENELITIAN}

Artikel ini pada mulanya merupakan penelitian yuridis empiris, yaitu sebuah penelitian hukum empiris yang bertugas memaparkan fakta hukum lewat pengamatan. (Sinamo, 2009). Pada dasarnya, hukum selalu bersifat normatif. Namun, dalam beberapa hal, hukum juga bisa ditampilkan dalam gejala-gejala dan praktik sosial. Dari sanalah hukum bisa dilihat dan dibandingkan antara sisi ideal (das sollen) dan sisi nyatanya (das sein). Kesenjangan antara dua sisi itulah yang melahirkan penelitian ini. Sedangkan sifat penelitian ini adalah bersifat deskriptif yaitu menggambarkan tentang implementasi deradikalisasi oleh FKPT Porpinsi Jambi. 


\section{HASIL PENELITIAN DAN PEMBAHASAN}

\section{Radikalisme dan Terorisme}

Kajian mengenai deradikalisasi sebaiknya dimulai dengan mengurai arti radikalisme yang merupakan sasaran dari gerakan ini. Dalam sejumlah literatur, istilah radikalisme seringkali bertumpang-tindih dengan pemaknaan lain dari gerakan atau ideologi serupa seperti fundamentalisme, ektremisme, terorisme dan sebagainya. Pemaknaan radikalisme mesti dilakukan secara hati-hati. Karena seringkali dimaknai secara pejoratif dan negatif, banyak orang yang enggan disebut sebagai radikal. Din Syamsuddin, misalnya, terangterangan menyebut bahwa wacana anti radikalisame menyakiti hati umat Islam (politik.rmol, 2019).

Radikalisme berasal dari kata "radikal" yang merupakan turunan kata dari "radix" (Latin) yang artinya akar (Golose, 2009), pangkal, bagian bawah, dan juga bisa berarti menyeluruh, habis-habisan dan amat keras untuk menuntut perubahan. Sejatinya ia merupakan cara berfikir falsafi yang berupaya mencari kebenaran dengan cara berfikir sampai ke akar permasalahan agar dapat mencapai hakikat pengetahuan demi mencapai kebijaksanaan.

Dalam perkembangannya, radikalisme menjadi faham yang dianggap negatif dan disamakan dengan ektremisme. Astrid Bötticher menganggap bahwa penyamaan radikalisme dan ekstremisme adalah pandangan yang tidak tepat. Dalam penelitianya, dia berkesimpulan bahwa apa yang dinamakan radikalisme itu sangat berbeda dari ekstremisme. Sementara ekstremisme mengandung kekerasan dan illegitimate, radikalisme, menurutnya lebih netral dan bisa legitimate. Ia menambahkan bahwa radikalisme dianggap sebagai faham atau gerakan yang mengandung kekerasan hanya oleh lawannya, biasanya oleh penguasa (Bötticher, 2017)

Sebagaimana ekstremisme, radikalisme biasanya merupakan respon atas setiap kondisi yang dianggap tidak ideal dan biasanya diikuti dengan gerakan sosial serta sikap anti kemapanan (Bötticher, 2017). Namun berbeda dari Bötticher, Khamami Zada justru menemukan bahwa radikalisme juga bisa bergerak lebih jauh untuk berupaya melakukan penggantian terhadap tatanan yang dianggap keliru kepada suatu bentuk lain yang mereka yakini kebenarannya. Sedemikian kuat keyakinan terhadap kebenaran ideologi yang mereka bawa - seraya menafikan kebenaran di luarnya - menjadikan kaum radikalis ini melakukan tindakan-tindakan yang mengatasnamakan kerakyatan atau kemanusiaan yang dapat mengakibatkan munculnya sikap emosional yang menjurus pada kekerasan (Khamami, 2002).

Apa yang dikemukakan Khammami menujukkan bagaimana radikalisme sangat potensial menggiring seseorang untuk melakukan tindakan ekstrem dan kekerasan. Dounia Bouzar menegaskan, "those radicalized beliefs lead to violence" (Bouzar, 2018). Terlebih, dalam perkembangannnya, radikalisme juga merasuki cara pandang terhadap agama namun dengan cara dan sikap yang keras. Banyaknya ayat-ayat yang berasal dari kitab suci yang menyeru pada jihad, amar makruf nahi munkar, dan misi transformasi sosial yang menjadi dalil utama yang dianggap sesuai dengan misi mereka. Tidak jarang, dalil ini juga menjadi konsumsi kebanyakan kelompok teroris.

\section{Deradikalisasi sebagai Respon terhadap Terorisme}

Sebagaimana dibahas pada halaman sebelumnya, penganggulangan terhadap kejahatan terorisme terbukti tidak dapat ditangani hanya dengan pendekatan represif. Diperlukan upaya-upaya yang lebih lembut dan dinilai lebih berkemanusiaan. Respon terkini terhadap terorisme itu dikenal dengan gerakan deradikalisasi, yaitu upaya menghilangkan sifat radikal pada diri seseorang. Radikalisme memang tidak persis sama dan tidak bisa disamakan dengan terorisme. Namun, menurut Ahmad Fuad Fanani, radikalisme kadang-kala bisa berubah menjadi terorisme, meskipun tidak semuanya dan selamanya begitu. Radikalisme 
sejatinya adalah satu tahapan atau satu langkah sebelum terorisme. Pada umumnya, para teroris yang banyak melakukan tindakan destruktif dan bom bunuh diri mempunyai pemahaman yang radikal terhadap berbagai hal, terutama soal keagamaan (Fanani, 2013).

Fakta bahwa radikalisme dipercaya sebagai pemicu utama terjadinya tindakan terorisme, karenanya, deradikalisasi dipercaya sebagai cara yang tepat untuk melakukan counter terrorism, upaya pencegahan dan pengendalian terhadap terorisme. Deradikalisasi sendiri dianggap sebagai langkah soft line approach untuk mengubah mindset tentang ideologi dan radikal, yang condong pada penyembuhan psikologi (Shodiq, 2018). Deradikalisasi umumnya difahami sebagai tindakan untuk menetralisir paham radikal yang melekat pada mereka yang terlibat aksi terorisme berikut para simpatisannya. Tujuannya agar mereka meninggalkan paham tersebut dan tidak terlibat lagi dalam aksi kekerasan (Shodiq, 2018). Namun, sebagai sebuah gerakan "kontra-ideologi terorisme, (Shodiq, 2018)" deradikalisasi dapat diperluas menjadi setiap upaya pencegahan terhadap setiap kegiatan dan faham radikal dan terorisme.

\section{Tentang FKPT Propinsi Jambi}

Pada mulanya, ekspektasi masyarakat yang begitu tinggi akan pentingnya penanganan paham radikal dijawab oleh Pemerintah dengan mengeluarkan Perpu Nomor 1 Tahun 2002, yang kemudian ditingkatkan menjadi Undang-Undangan Nomor 15 Tahun 2003 tentang Pemberantasan Tindak Pidana Terorisme. Namun UU tersebut belum mencakup aspek pencegahan bagi penyebaran kebencian dan rehabilitasi bagi mereka yang telah mengalami proses hukum dan kembali kepada masyarakat. Karenanya, untuk mengisi kekosongan itulah dibentuk Badan Nasional Penanggulangan Terorisme (BNPT) pada 16 Juli 2010 (Idris, 2017).

Pada perkembangan selanjutnya, BNPT berupaya lebih melebarkan sayap institusi pencegahan radikalisme di Indonesia. Berdasarkan peraturan Kepala BNPT Nomor Perka/01/BNPT/10/2012 tetang Tata Kerja Badan Nasional Penanggulangan Terorisme, pada pertengahan awal tahun 2012 dilakukan pembentukan suatu wadah khusus yang diharapkan menjadi mitra strategis dan perpanjangan tangan BNPT di daerah dalam memasyarakatkan eksistensi badan negara ini, serta untuk mengajak seluruh komponen bangsa dan segenap lapisan masyarakat mewaspadai bahaya radikalisme dan teorisme. Sebuah forum bernama FKPT (Forum Koordinasi Pencegahan Terorisme) akhirnya dibentuk di bawah Kedeputian 1 Direktorat Deradikalisasi BNPT pertama kali di Nusa Tenggara Barat (Idris, 2017)

Jambi merupakan Provinsi ke-27 dengan kepengurusan definitif dari total 33 Provinsi yang dirangkul BNPT melalui pembentukan forum koordinasi. Melalui pembentukan forum koordinasi ini diharapkan program nasional untuk melakukan upaya preventif terhadap perkembangan terorisme dapat dilakukan secara optimal. Pembentukan kepengurusan Forum Koordinasi Pencegahan Terorisme (FKPT) di Provinsi Jambi sendiri berlangsung pada tanggal 5-6 Agustus 2015 oleh BNPT. Kegiatan ini melibatkan berbagai unsur masyarakat yang selama ini concern dalam upaya pencegahan paham radikalme dan terorisme, antara lain adalah elemen Pemerintah, tokoh agama, tokoh masyarakat, tokoh pendidikan, tokoh pemuda dan perempuan, serta organisasi pers (indonesiaku, 2019).

FKPT dibangun dengan tujuan untuk mewujudkan masyarakat yang sadar dan paham terhadap ancaman dan bahaya terorisme dalam kehidupan bermasyarakat, berbangsa, dan bernegara, memberikan pemahaman kepada masyarakat untuk menghadapi segala bentuk ancaman radikal terorisme, dan mencegah berkembangnya paham radikal terorisme di daerah, dengan satu visi, yaitu "tumbuhnya kesadaran masyarakat tentang ancaman dan bahaya terorisme dengan berbasis pada nilai kearifan lokal guna mewujudkan masyarakat indonesia yang damai" (Abd Rauf: 2018). 
Untuk mengembangkan visi dan tujuan tersebut, FKPT memiliki misi membantu

BNPT dalam rangka deradikalisasi di daerah. Selengkapnya misi FKPT ialah:

“1) Membantu BNPT dan Pemerintah Daerah dalam mencegah penyebaran paham radikal terorisme; 2) Melakukan gerakan penyadaran atas ancaman dan bahaya terorisme didaerah secara berkelanjutan, terukur, dan sesuai dengan kearifan; 3) Meningkatkan kesadaran dan kewaspadaan dini di Daerah melalui penanaman dan pengamalan nilai-nilai Pancasila dan UUD 45; 4) Menumbuhkan kearifan lokal yang menghargai keragaman masyarakat di Daerah; 5) Mengkoordinasikan kegiatankegiatan dalam menghadapi bahaya terorisme dengan berbagai unsur masyarakat dan pemangkau kepentingan di Daerah. (Abd Rauf: 2018).

\section{Pelaksanaan Deradikalisasi oleh FKPT di Propinsi Jambi}

Forum Koordinasi Pencegahan Terorisme (FKPT) Propisni Jambi di bawah Badan Nasional Penanggulangan Terorisme (BNPT) sebagai lembaga pemerintah non kementerian yang diamanatkan menangani terorisme berusaha mengedepankan aspek pencegahan yang bersifat lunak dalam upaya mewaspadai berkembangnya radikalisme dan terorisme yang membajak kepercayaan tertentu masyarakat. Diyakini bahwa pendekatan lunak dalam berbagai bentuk merupakan metode yang efektif meningkatkan daya tangkal masyarakat luas dan menolak ajakan kekerasan yang diinisiasi kelompok radikal terorisme.

Sebagai perpanjangan dari visi dan misi, serta tujuan dari BNPT, upaya deradikalisasi FKPT Propinsi Jambi dilaksanakan dengan mengedepankan kerja-kerja preventif, yaitu upaya cegah faham radikal dan secara dini menumbuhkan kewaspadaan terhadap kemungkinan aksi terorisme yang bisa terjadi di manapun di pelosok negeri.

Pelaksanaan deradikalisasi melalui metode soft approach ini diupayakan berlangsung secara berkesinambungan dan sistemik dengan melibatkan berbagai pihak. Cara-cara seperti ini dilakukan juga karena sesuai dengan komposisi pengurus yang terdiri dari berbagai bidang yang meliputi: bidang pemberdayaan agama, pendidikan dan dakwah; bidang pemberdayaan hukum dan ekonomi; bidang pemberdayaan pemuda dan perempuan; bidang pemberdayaan media, humas, dan sosialisasi; dan bidang pengkajian dan penelitian (Idris, 2017)

Realisasi kerja deradikalisasi yang dilakukan FKPT Propinsi Jambi dapat dirumuskan dalam berbagai langkah berikut:

1. Penyuluhan kepada masyarakat

Upaya ini dilakukan dengan cara meneyelenggaran acara dengan menghadirkan tokoh-tokoh baik dari institusi pendidikan, LSM, kepolisian, maupun tokoh masyarakat guna menyampaikan tema-tema terkait dengan masalah dan bahaya radikalisme dan terorisme. Penyuluhan ini juga berguna untuk menanamkan rasa cinta terhadap Negara Kesatuan Republik Indonesia dan mengajak masyarakat untuk melindungi falsafah Negara. Semua ini bersinergi dengan upaya mensosialisasikan Undang-Undang Terorisme agar dimengerti dan dapat dilaksanakan oleh masyarakat.

Hal yang juga menjadi sangat penting dalam setiap penyuluhan adalah upaya penguatan nilai-nilai agama yang moderat vis a vis ekstremisme. Komposisi pengurus FKPT Propinsi Jambi tampaknya cukup memadai untuk memberikan materi-materi terkait masalah agama ini. Ketua maupun beberapa anggota pentingnya berasal dari perguruan tinggi agama ternama di Jambi.

Baru-baru ini FKPT Provinsi Jambi juga melakukan kegiatan Rembuk Aparatur Kelurahan dan Desa tentang Literasi Informasi dengan tema saring sebelum sharing di salah satu hotel di Kota Jambi. Rembuk ini dihadiri oleh aparatur kelurahan dan desa serta puluhan Babinsa dan Babinkamtibmas. Menurut Kasubdit Pemberdayaan Masyarakat Badan Nasional Penanggulangan Teroris (BNPT), Andi Intang Dulung, yang menjadi narasumber pada acara ini, bahwa terorisme berkembang salah satunya akibat kemajuan tekhnologi. 
Karena itu ia berharap Babinsa dan Babinkamtibmas untuk memantau dan memberikan pemahaman kepada masyarakat tentang manfaat saring informasi sebelum sharing terutama informasi-informasi tentang radikalisme dan terorisme (imcnews.id, 2019).

2. Pendidikan dan pelatihan

Pelatihan merupakan salah satu program yang juga dilakukan oleh FKPT Propinsi Jambi. Salah satu bentuk pelatihan itu antara lain adalah diskusi bertajuk Literasi Media Sebagai Upaya Cegah dan Tangkal Radikalisme dan Terorisme. Menurut salah satu pemateri:

"Persoalan terorisme tidak dapat dilepaskan dari pengaruh media / internet. Media internet memiliki algoritma yang bisa mengarahkan seseorang pada passion atau hobinya. Dengan algoritma ini, setiap orang akan dimasukkan pada kelompok orang yang memiliki hobi yang sama yang bisa dilihat dari jejak searchingnya. Inilah yang kemudian dikenal dengan istilah bubble zone. Dengan demikian, mereka yang terpengaruh pada faham radikal tidak jarang adalah mereka yang sercara tidak sengaja mendapatkan informasi terus-menerus dari website yang menawarkan berita seputar ideologi teororis. Karena itu, solusi untuk menangkal algoritma atau bubble syndrom ini adalah memberikan kesadaran kepada setiap pengguna untuk tidak terpengaruh pada kontek-konten radikal yang ditawarkan kepadanya" (wawancara, 15/8/2019).

Pelatihan biasanya dilakukan melalui kerjasama dengan lembaga tertentu seperti Kementerian Agama. Selain pelatihan di atas, pelatihan lain yang pernah diberikan ialah pelatihan para penyuluh agama di Propinsi Jambi. Diharapkan melalui kegiatan tersebut, para penyuluh agama sebagai ujung tombak dalam memberikan dakwah kepada masyarakat memiliki pemahaman yang memadai akan bahaya radikalisme dan terorisme serta mengetahui cara pencegahannya. Para penyuluh tersebut diberikan pemahaman tentang pentingnya kearifan lokal sebagai salah satu tameng utama untuk mencegah radikalisme dan terorisme.

Dalam pelaksanaannya, para penyuluh agama tersebut diberikan pelatihan berupa tulisan-tulisan cinta, kasih dan damai yang dirangkai dalam bentuk buku Dakwah Nusantara Berkemajuan dengan judul "Ayat-Ayat Damai". Melalui pelatihan ini pula, BNPT dan FKPT Jambi bekerjasama dengan penyuluh agama memberikan pemahaman rahmatan lil alamin kepada masyarakat agar menjadi karakter manusia Indonesia yang cinta damai, cinta tanah air, serta cinta persatuan dan kesatuan (Penyusun, 2018).

3. Kerjasama

Seperti dikemukakan di atas, FKPT dalam melaksanakan kegiatannya tidak bekerja sendiri. Forum ini selalu bekerja dengan institusi lain di Propinsi Jambi, seperti Kementerian Agama, lembaga pendidikan, Pemerintah Daerah, LSM, Pers, maupun masyarakat luas. Kerjasama ini menjadi sangat penting artinya, bukan saja oleh pihak FKPT melainkan juga oleh lembaga yang terlibat dalam kerjasama tersebut. Semacam simbiosis mutualisme dalam mensukseskan program masing-masing. Namun lebih dari itu kerja sama ini sangat penting agar kegiatan deradikalisasi benar-benar berjalan secara multi arah dan simultan.

Deradikalisasi pada dasarnya merupakan upaya pendidikan karakter guna menumbuhkan sifat-sifat terpuji yang bisa membentengi diri melawan setiap paham-paham radikal yang ekstrem. Dalam FKPT, peberdadyaan agama, pendidikan, dan dakwah merupakan bidang yang paling banyak terlibat dalam kerjasama. Ini tampaknya sesuai dengan karakter dan komposisi masyarakat Jambi yang mayoritas beragama Islam serta memegang satu falsafah adat bersendi syara', syara' bersendi Kitabullah. Selain itu, tematema agama merupakan isu yang paling relevan dengan masalah radikalisme. Sehubungan itu, dalam menjalankan fungsinya, bidang ini biasanya bekerja dengan Forum Komunikasi Umat Beragama (FKUB), Majelis Ulama Indonesia (MUI), dan Kementerian Agama di 
Propinsi Jambi maupun lembaga-lembaga pendidikan seperti pesantren maupun perguruan tinggi Islam.

Kerjasama dengan institusi agama tersebut menjadi urgen karena di sana terdapat sejumlah ahli-ahli agama yang diharapkan dapat menjadi penyambung lidah dan media penyaluran visi dan misi serta tujuan FKPT. Realisasinya biasanya dalam bentuk seminar, ceramah-ceramah, khutbah, safari Ramadhan yang di sana disampaikan secara langsung maupun tidak langsung mengenai materi-materi terkait cara beragama yang rahmatan lil alamain vis a vis radikalisme. Kegiatan-kegiatan semacam ini dilaksanakan baik di sekitar Kota Jambi maupun di Kabupaten-Kabupaten di Propinsi Jambi. Menurut Ketua FKPT Jambi, Ahmad Syukri, berbagai kegiatan dilakukan mengundang para penyuluh agama dan pihak terkait lainnya. Kegiatan seperti ini cukup mencolok mengingat atensi dari peserta yang luar biasa yang berasal dari kalangan siswa, mahasiswa, pegiat literasi, wartawan, Babinsa dan Bhabinkamtibmas (imcnews.id, 2019).

Selain dengan tokoh agama, FKPT Propinsi Jambi juga bekerjasama dengan pers. Melalui pers diharapkan pesan-pesan moril dari FKPT dapat disosialisasikan secara massif ke tengah masyarakat. Karena itu hampir setiap kegiatan FKPT Propinsi Jambi selalu diliput oleh media Jambi. Untuk memperlancar kegiatannya dan hubungannya dengan pers, FKPT melibatkan pihak pers sebagai salah satu anggota FKPT Propinsi Jambi.

Beberapa wawancara maupun observasi menunjukkan bahwa FKPT berupaya melaksanakan program deradikalisasi secara efektif dan efisien. Ini terlihat dari bagaimana FKPT lebih banyak mendekati agen-agen yang dianggap dapat menjadi pialang (broker) untuk mendiseminasi ajaran-ajaran kontra radikalisme seperti guru, LSM, tokoh masyarakat, atau $d a{ }^{\prime} i$. Selain contoh-contoh kegiatan yang telah dipaparkan di atas, kegiatan FKPT juga menyasar para guru seperti kegiatan yang bertajuk "Harmoni Dari Sekolah; Integrasi Nilai-Nilai Agama Dalam Menumbuhkan Harmoni Kebangsaan" (metrojambi.com, 2019).

Menurut salah seorang mantan anggota FKPT Porpinsi Jambi, "pelaksanaan program deradikalisasi di Jambi berjalan masih dalam bentuk yang seporadis. Hal ini tergantung dari pendanaan yang ada. Selain itu, pelaksanaan program deradikalisasi masih bertumpu pada kalangan elit. Program ini hampir tidak menyentuh masyarakat bawah yang sejatinya merupakan sasaran utama deradikalisasi" (Wawancara, 3/9/2019).

Kompleksitas permasalahan yang ditimbulkan oleh radikalisme di kalangan masyarakat sangat menuntut pendekatan yang sistematis dan berkelanjutan. Diperlukan kesamaan visi dan pandangan mengenai radikalisme berserta bahaya yang mungkin diakibatkannya. Tanpa hal itu, kerja-kerja deradikalisasi tampak hanya menjadi acara seremonial yang kurang tepat sasaran dan tidak mampu mebuahkan hasilkan sebagaimana yang diinginkan, yaitu mencitptakan masyarakat yang sehat dan terbebas dari pengaruh dan faham radikalisme.

\section{Dampak Deradikalisasi dalam Meningkatkan Kesadaran Masyarakat tentang Bahaya Terorisme}

Di Jambi, potensi radikalisme dan terorisme tidak bisa dipandang sebelah mata. Beberapa hasil wawancara menunjukkan bahwa potensi gerakan radikalisme cukup kuat di Propinsi ini. Dikatakan bahwa "beberapa kawasan hutan menjadi bais pelatihan kelopok teroris yang merupakan jaringan luas di Indonesia. Jambi diminati karena tempatnya yang relatif tenang dan jauh dari pengawasan pihak berwajib" (Wawancara, 8 /8/2019). Awal bulan Juni, tepatnya tanggal 7 Juni 2018, Tim Densus 88 Anti Teror Polri menangkap dua terduga teroris jaringan Jamaah Ansharut Daulah (JAD) di Kabupaten Bungo, Provinsi Jambi.Kedua terduga teroris masih satu jaringan dengan Eka yang merupakan pelaku penyerangan dan pembakaran Polres Dharmasraya, Sumatera Barat. Eka juga tercatat sebagai anggota JAD yang merupakan kelompok teror di Surabaya dan Riau beberapa 
waktu lalu (newsplus.antvklik.com, 2019). Dengan potensi faham radikal dan aksi terorisme di Jambi, maka upaya membangun kesadaran masyarakat untuk menangkal faham radikal ini sangat perlu dilakukan.

Secara umum, dari peran yang telah dimainkan oleh FKPT di atas, tampak bahwa fungsi-fungsi deradikalisasi sebenarnya sudah berjalan. Dengan kata lain, kehadiran FKPT di kota Jambi telah banyak memberikan manfaat bagi upaya melakukan deradikalisasi di tengah masyarakat. Sekalipun demikian, untuk menguji sejauh mana program deradikalisasi oleh FKPT sudah berhasil, paling tidak dapat dilihat dari sejauh mana masyarakat memiliki kesadaran tentang bahaya radikalisme dan terorisme, yang antara lain dapat diukur dari sikap masyarakat berikut:

Pertama, mampu mendeteksi setiap gejala-gejala ke arah radikalisme. Hal ini sangat penting bagi masyarakat karena ketidakmampuan mengenali gejala radikalisme menjadi peluang bagi masuknya faham-faham radikalisme itu sendiri. Belakangan, ujaran-ujaran kebencian dengan mengatasnamakan agama masih sangat marak, terutama saat Pilpres 2019. Ujaran-ujaran kebencian, misalnya, dapat disaksikan dengan mudah dari beragam konten di media sosial yang menampilkan ceramah-ceramah yang cenderung profokatif. Sayangnya, hal demikian tampak banyak diamini oleh masyarakat dan menganggap hal tersebut sebagai bagian dari strategi dakwah yang memang diperlukan dalam menyebarkan agama. Pandangan demikian tampak massif di kalangan masyarakat. Beberapa tokoh masyarakat yang penulis temui menyatakan sebagai berikut: "saat ini dalam agama ada agen-agen yang ingin merusak agama Islam secara sistematis. Karena itu perlu sikap tegas untuk melawan kecendrungan tersebut" (Wawancara, 8/6/2019).

Pandangan-pandangan masyarakat di atas mengindikasikan bahwa gerakan deradikalisasi dengan maksud menyebarkan agama yang lembut dan damai tampak kurang bekerja sejauh ini. Meski perlu diakui bahwa masyarakat pada umumnya kurang menyukai faham radikal, namun dalam praktiknya mereka sepertinya belum mengetahuai dan belum mampu memberi garis demarkasi antara agama yang toleran dan yang bernada kekerasan. Sebagai contoh, keterlibatan masyarakat dalam membendung faham Hizbut Tahrir yang sudah dibubarkan pemerintah tergolong sangat rendah. Hal ini karena Hizbut Tahrir cendrung menggunakan agama sebagai cara dan tujuannya. Penggunaan agama di ruang publik - seperti simbol-simbol bendera - inilah yang menjadikan masyarakat tidak mampu mengenali potensi radikalisme di dalamnya. Terlebih gaya kelompok radikal saat ini cendrung menggunakan cara-cara yang lembut seperti tampak dalam ceramah-ceramah.

Kedua, menjauhi dan membentengi diri dan keluarga dari pengaruh-pengaruh radikalisme dan terorisme. Terkait masalah ini, masyarkat menunjukkan sikap yang positif dan proaktif. Dengan kata lain pandangan masyarakat terhadap radikalisme dan terorisme sangat negatif. Namun, dalam praktinya, faham radikalisme dan terorisme bisa dengan mudah bersarang dalam benak masyarakat.

Berdasarkan observasi dan wawancara dengan sejumlah masyarakat di Jambi, didapati bahwa masyarakat kurang mengetahui cara melindungi diri dari radikalisme dan terorisme. Ini disebabkan karena mereka kurang mengetahui dan tidak mampu mengindentifikasi fenomena radikalisme dan teororisme di kalangan masyarakat, terutama yang berlindung di baling narasai-narasi agama. Ini persis seperti yang diungkapkan oleh Direktur Deradikalisasi Badan Nasional Penanggulangan Terorisme (BNPT), Irfan Idris, bahwa banyak bukti menguatkan bahwa agama dapat dipergunakan sebagai cover dalam melampiaskan emosi dan birahi politik atas nama agama (Idris, 2017)

Ketiga, kesediaan bekerja sama secara aktif dengan aparat kepolisian dalam mengungkap setiap aksi dan gerakan radikalisme dan terorisme. Bagian ini menjadi penting karena di samping membutuhkan kemapuan untuk mengendus faham-faham radikal dan teroris, juga diperlukan keberanian untuk melaporkan kepada aparat atau pihak berwajib. 
Pada kenyataannya, beberapa kasus terorisme di Jambi berada di luar pengetahuan masyarakat seperti kasus penangkapan terduga terduga teroris yang diamankan Densus 88 Antiteror, Senin, 29 Mei 2017, di kawasan Rukun Tetangga (RT) 35, Kelurahan Kenali Besar, Kecamatan Alam Barajo, Kota Jambi. Menurut keterangan RT setempat bahwa dia sama sekali tidak pernah mengetahui bahwa terduga teroris ditangkap aparat (Densus 88 Antiteror) ternyata adalah warganya. Demikian pula masyarakat merasa kecolongan dan tidak mengetahui bahwa orang tersebut adalah seorang yang memiliki jaringan dengan teroris. Keterangan masyarakat dan RT hanya bahwa yang bersangkutan tidak pernah melapor dan cendrung sangat pendiam dan terkesan anti sosial (nasional.tempo.com, 2019).

Menilik faktor-faktor di atas, dapat difahami bahwa program-program deradikalisasi di Jambi masih belum efektif dalam hal memberikan pengetahuan dan pemahaman secara komprehensif tentang bahaya laten dari radikalisme dan terorisme yang sewaktu-waktu dapat muncul dalam waktu yang tidak dapat diduga. Keterbatasan sumber daya FKPT tampaknya menjadi alasan utama bahwa program-program yang dijalankan belum begitu membumi di tengah masyarakat akar rumput. Berkenaan dengan hal ini, Muhammad Abid mengomentari bahwa deradilisasi belum berjalan secara optimal karena masalah radikalisme terbilang sangat kompleks tidak bisa ditangani oleh satu institusi saja dengan segala keterbatasannya (Wawancara, 15/8/2019).

Selain itu, diakui bahwa dalam pelaksanaan tugasnya, FKPT menghadapi beberapa kendala di antaranya: pertama, penguatan kelembagaan yang belum memiliki dasar hukum yang memadai; kedua, respon sebagian masyarakat yang masih menganggap bahwa isu radikalisme dan terorisme merupakan pesanan asing; dan ketiga, masih adanya anggapan sebagian masyarakat bahwa menanggulangi terorisme itu adalah tugas aparat keamanan saja (Idris, 2017).

Penanggulangan terorisme melalui upaya deradikalisasi oleh FKPT pada dasarnya telah berjalan secara terporgram. Kendati demikian, temuan-temuan di lapangan menunjukkan bahwa program tersebut belum mampu menyentuh akar rumput. Ini menyebabkan faham-faham radikal dan terorisme masih terus ada. Indoktrinasi paham radikal masih jauh lebih massif, terprogram, sistematik, dan berkesinambungan dibandingkan dengan upaya dan kerja deradikalisasi.

\section{SIMPULAN}

Berdasarkan pemaparan dan analisis dari permasalahan di atas, beberapa kesimpulan dapat diuraikan sebagai berikut. Pelaksanaan deradikalisasi oleh FKPT di Propinsi Jambi dilakukan dengan cara efektif dan efisien. Artinya program deradikalisasi dilakukan dengan konsep minimal dengan hasil yang besar. Ini tentu terkait dengan keterbatasan pendanaan dan sumber daya yang tersedia. Caranya ialah dengan melakukan kerjasama dengan pihakpihak terkait yang memiliki jaringan yang luas atau massa yang besar seperti lembaga pendidikan, LSM, tokoh masyarakat, tokoh agama maupun media. Mereka ini diharapkan dapat menjadi agen-agen yang dianggap dapat menjadi pialang (broker) untuk mendiseminasi ajaran-ajaran kontra radikalisme.

Dampak deradikalisasi dalam meningkatkan kesadaran masyarakat tentang bahaya terorisme di Jambi masih menemui kendala yang sifatnya mendasar, di antaranya ialah penguatan kelembagaan yang belum memiliki dasar hukum yang memadai, respon sebagian masyarakat yang masih menganggap bahwa isu radikalisme dan terorisme merupakan pesanan asing, dan masih adanya anggapan sebagian masyarakat bahwa menanggulangi terorisme itu adalah tugas aparat keamanan saja. Akibatnya, fungsi deradikalisasi oleh FKPT Propinsi Jambi tampak belum menyentuh akar rumput.

Upaya melakukan deradikalisasi merupakan proses menciptakan lingkungan yang damai dan sekaligus mencegah segala tindakan yang mengarah pada kekerasan. Upaya ini sajatinya berjalan secara sistematis dengan melibatkan banyak unsur yang saling terkait. 
Penelitian ini menyarankan agar FKPT dapat lebih memperluas kerjasama, terutama dengan pihak universitas di mana sasaran radikalisme banyak terjadi. Secara program kerja, pihak FKPT sejatinya mampu mengkoordinir kegiatan-kegiatan yang intensif dan berkesinambungan dengan cara lebih mengaktifkan kerja dari para broker. Termasuk mengaktifkan RT-RT untuk lebih mengawasi warganya dari serangan dan pengaruh faham radikal dan terorisme.

\section{DAFTAR PUSTAKA}

Bötticher, A. (2017). Towards Academic Consnsus Definitions of Radicalism and Extrimism. Perspectives on terrorism, 11(4), 73-77.

Bouzar, D. (2018). Stages of the radicalization and deradicalization process. Practicies Project (No. 740072). Objective H2020-SEC-06-FCT-2016 Research and Innovation Action (RIA) Partnership against violent radicalization in cities, Project.

Fanani, A. F. (2013). Fenomena Radikalisasi di Kalangan Muda. Maafif, 5.

Golose, P. R. (2009). Deradikalisasi Terorisme, Humanis, Soul Approach dan Menyentuh Akar Rumput. Jakarta: Yayasan Pengembangan Kajian Ilmu.

Heryansyah, D. \&. (2018). Problems of Law Enforcement and Ideas of Paradigm Prophetic in Indonesia. Jambe Law Journal, 1(1), 91-114.

Idris, I. (2017). Membumikan Deradikalisasi: Soft Approach Model Pembinaan Terorisme dari Hulu ke Hilir Secara Berkesinambungan. Jakarta: Daulat Press.

imcnews.id. (2019, Juli 27). imcnews.id. Retrieved from imcnews.id: http://www.imcnews.id indonesiaku, d. (2019, agustus 6). damailahindonesiaku.com. Retrieved from damailahindonesiaku.com: https://damailahindonesiaku.com

Khamami, Z. (2002). Islam Radikal : Pergulatan Ormas-Ormas Islam Garis Keras di Indonesia. Jakarta: Teraju.

metrojambi.com. (2019, September 4). metrojambi.com. Retrieved from metrojambi.com: http://metrojambi.com

Monalisa, S. R. (2019). A Comparative Study on Criminal Sanction Against Drugs Offenders. Jambe Law Journal, 2(2).

nasional.tempo.com. (2019, Agustus 25). nasional.tempo.com. Retrieved from nasional.tempo.com: http://nasional.tempo.com

newsplus.antvklik.com. (2019, September 8). newsplus.antvklik.com. Retrieved from newsplus.antvklik.com: https://newsplus.antvklik.com

Penyusun, T. (2018). Laporan Kegiatan Penguatan Kapasitas Penyuluh Agama dalam Menghadapi Radikalisme Melalui FKTP Jambi. Jambi: Subdit Pemberdayaan Masyarakat Direktorat Pencegahan. 
politik.rmol. (2019, Oktober 23). Din Syamsuddin: Wacana Anti Radikalisme Menyakiti Hati Umat Islam. Retrieved Januari 23, 2020, from Politik.rmol:

https://politik.rmol.id/read/2019/10/23/407594/din-syamsuddin-wacana-antiradikalisme-menyakiti-hati-umat-islam

Sarwono, S. W. (2012). Terorisme di Indonesia dalam Tinjauan Psiokologi. Jakarta: Alfabet dan LaKIP.

Shodiq, M. (2018). Paradigma Deradikalisasi dalam Prespektif Hukum. Jakarta: Pustaka Harakatuna.

Sinamo, N. (2009). Metode Penelitian Hukum. Jakarta: PT. Bumi Intitama Sejahtera.

tirto.id. (2019, Februari 25). tirto.id. Retrieved from tirto.id: https://tirto.id/tumpulnya-bnptmelempemnya-deradikalisasi-kr

Zen, F. (2012). Radikalisme Retoris. Jakarta: Bumen Pustaka Emas.

\section{Wawancara:}

Wawancara dengan MA, tanggal 15 Agustus 2019.

Wawancara dengan HG, tanggal 3 September 2019

Wawancara dengan salah seorang anggota Badan Intelijen Nasional Propinsi Jambi pada 8 Agustus 2019.

Wawancara dengan tokoh masyarakat, tanggal 8 Juni 2019. 